\title{
Impact of Using Technology on Teacher-Student Communication/Interaction: Improve Students Learning
}

\author{
Erkan Akyürek ${ }^{1, *}$ \\ ${ }^{1}$ Secondary School of Inegol Atatürk, Turkey Ministry of Education, Bursa, Turkey \\ *Correspondence: Secondary School of Inegol Atatürk, Turkey Ministry of Education, Bursa, Sinanbey Street., No: \\ 31/A 16400, Turkey. Tel: 90-505-453-5153. E-mail: erkanakyurek@hotmail.com
}

Received: May 30, 2019

Accepted: July 5, 2019 Online Published: July 17, 2019

doi:10.5430/wje.v9n4p30

URL: https://doi.org/10.5430/wje.v9n4p30

\begin{abstract}
This paper aims to investigate the teachers' and students' views on using technology and its effect on communication/interaction. As noteworthy results have been succeeded in educational technology in recent years, evaluating the effects of technology integration on communication is now possible. Moreover, the impact of technology on the teachers' and students' communication is considered important. The present study examines the factors or the impact of using technology between teacher-student communication/interaction in Turkey. This paper proposes both innovation diffusion theory (IDT) and integrating technology acceptance model (TAM) from educational communication perspectives. The case study method was used in the research. Case study is one of the qualitative approaches and requires in-depth analysis of a case resulting in a narrative description of behaviour or experience of a person or a group. The sample of this study consists of 95 participants (77 students and 18 teachers) from a secondary school in Bursa/Turkey. Semi-Structured interviews were carried out with the participants including issues; "using education technology on teacher and student technologies, the effect of using education technology and to improve teacher-student communication should be used asolution proposals for technologies in classrooms". Maxqda 11 program was used for the analysis of the interviews. As a result of the interviews, participants have been suggested to use tablets in classrooms, sound insulation, use of never ending pen and no ringtones. The findings show that the choice of educational technology is related to teachers' perception which is communication/interaction with the student can be enhanced using technology. However, the opposite is true for students.
\end{abstract}

Keywords: education technology, communication, interaction, teacher, student, improve

\section{Introduction}

In integration of technologies to community, different factors influencing communication/interaction might lead to the failure of the whole education. Despite the potential positive impact of educational technology, more research is needed to design appropriate usage of technology in schools (Akyürek, 2019, Dhir et al., 2013). For years instructional communication scholars have enacted how to use technologies appropriately (Jwaifell, 2018) between teachers and students with an aim to improve students learning and teaching effecttiveness. In consequence, the overarching aim of the present research is to explore in depth the teachers' and pupils' perceptions of the impact of educational technology on learning in primary education, and how these perceptions could influence the use of educational technology in the learning process. What types or forms of communications and interactions between students and teachers are to improve student learning? Therefore, this article explores the teachers' and students' views on using technology and its impact on communication and suggesting interaction pattern.

Concerns about integrating technology into education around the world have been proportionate to the transition from teacher-centered education to student-centered education (Akyürek, 2018, Trucano, 2005). It is argued that the student-centered environment is better than the teacher-centered environment with the possibilities of knowledge construction (Roblyer, Edwards, \& Havriluk, 2004), critical thinking (Jonassen, 2000) and higher achievement (Lim $\&$ Chai, 2008). Using technology in the lesson has been perceived by the students as a greater connection, a greater level of satisfaction while working, more teacher support, and more active participation during the classes (Fiksl, Flogie, \& Abersek, 2017). The increase in using technology reveals not only innovations but also some complex situations (Smeets, 2005). The necessity to examine the concept of communication in contemporary education 
technology, all the activities and barriers carried out in the learning-teaching processes are basically due to the communication activity (Akyürek \& Afacan, 2018). The educational technologies used to communicate with students vary according to location and time. In interaction between humans, the body language has a share of $55 \%$, sound $38 \%$, words $7 \%$. In education, how the message between the teacher and the recipient (student) is presented plays a very important role. Feedback from these two important actors determines the format of the presentation of the message. The elements of the feedback from the student and teacher consist of ideas, information, feelings, attitudes, and skills.

\subsection{Interactive Whiteboard (Smart Board) in Turkey}

In Turkey, the pilot implementation has been initiated within Fatih project in 17 provinces and 52 schools in 2012-2013 academic years. As of 2015, a SMART Board was established in 432.000.288 classrooms in 45.000.653 schools throughout Turkey. A huge budget expenditure of approximately $\$ 355$ million was made (MEB, 2015). One of the important aspects of the survey is that this huge budget for education expenditure shows the benefit ratio. The findings showed that the existing studies primarily focused on the following themes: effects on student achievement (Crocker \& Mazer, 2018), changes to the classroom environment (Asino \& Pulay, 2019), classroom uses (Siefert et al., 2019), effects on learner motivation and engagement (Zhang \& Liu, 2019), and challenges to classroom integration (Grigorenko, 2019). What are the effects in the existing research on these specific technologies and their effects on student-teacher communications? Current study and its findings address this research gap and help to advance/contribute to prior related research findings.

Information technologies in education are probably often related to appropriate computer technologies and the Internet (Vincentas \& Rytis, 2007). Needs-based technology integration education is shown to have a rapid, positive effect on teacher attitudes, such as perceived importance of computers, and computer enjoyment (Christensen, 2002). Despite all investments on information and communication technology infrastructure, equipments and professional development to improve education in many countries, information and communication technology adoption and integration in teaching and learning have been limited (Andoh, 2012). Studies on the technology used in education are concentrated on computer and Internet database (Koh \& Frick, 2009), pre-service teachers' abilities, beliefs (Anderson \& Manninger, 2007; Al-Awidi \& Alghazo, 2012) or understanding use of technology by classroom teachers (Britten \& Cassady, 2006). However, the technology used in classrooms and the impact of this on communication is not on the computer only.

The main problem of the research 'What is the impact of educational technology in teacher-student communication?', 'Which technologies do we have to use to support or facilitate student-teacher communications/interactions?', 'What studies do we have to conduct to determine the efficacy of each technology on students' and teachers' ability to engage in the specific form of communication/interaction?'. In this context, sub-problems are determined: 'What technologies do you use in your classroom?', 'How often do you use it?, 'Do you think lessons learned with these technologies are effective, why?' 'When the technologies in the classroom are taken into account, which technologies affect teacher-student communication?' 'What technologies would you like to use in your classroom to communicate better with your teacher/students to handle the lessons better?'. This study is important because it examines and compares the technologies used in the classroom from both teacher and student perspectives.

\subsection{Theoretical Background}

In this study, the authors are looking from technology integration perspective and educational communications perspective. As demonstrated in Figure 1, both Diffusion of Innovations and Technology Acceptance Model used and integrated educational communications perspective in Instructional Communication as Interaction model. 


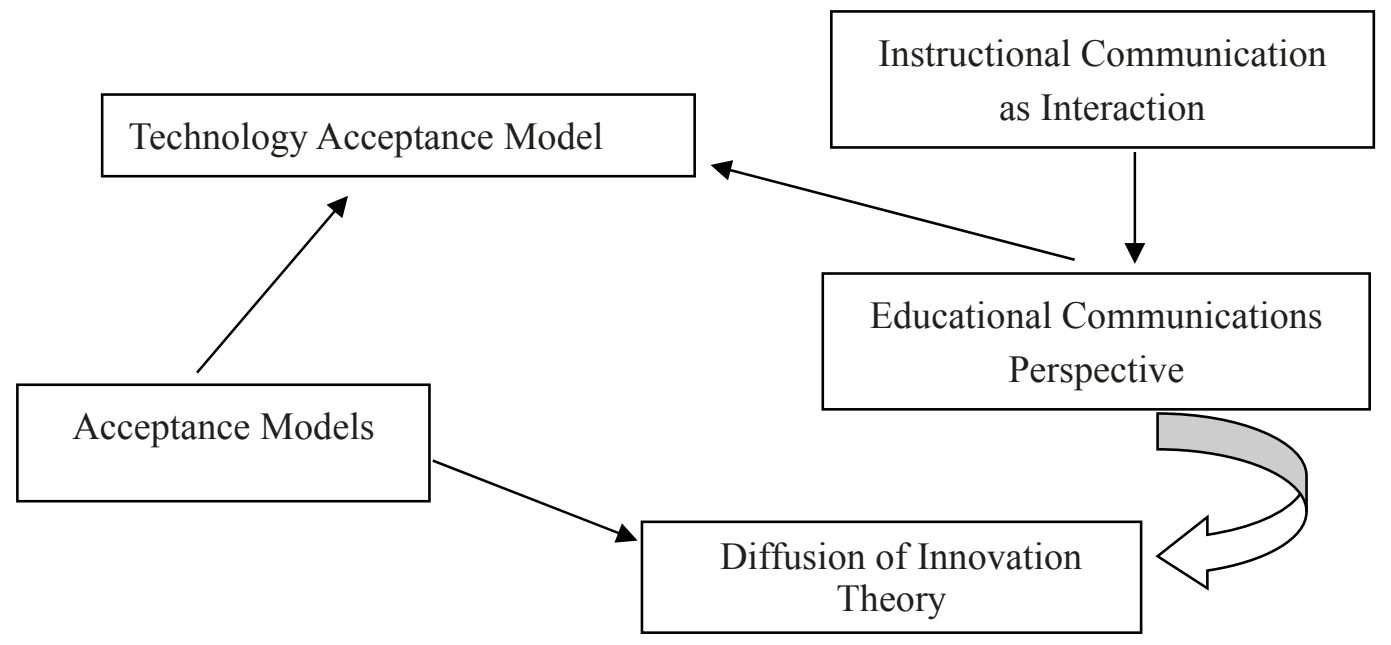

Figure 1. Acceptance Models

\subsubsection{Technology Acceptance Model}

The Technology Acceptance Model explains core variables of teachers' and students' motivation; 1) attitudes toward technology, 2) perceived ease of use, 3) perceived usefulness and outcome variables; 1) technology use, 2) behavioral intentions 3) user training 4) system characteristics. Of three variables, perceived usefulness and perceived ease of use are considered two major beliefs that are directly related to attitudes toward technology and considerable impact on the outcomes (Marangunić \& Granić, 2015). Technology Acceptance Model refers to the actual use of technology. In the Technology Acceptance Model, positive user experience may play a role in determining the future behavioral intentions (Straub, 2009). Nistor (2014) determined that the link between use intentions (adopt the technology or reject it) and actual use is often missing in empirical studies of the Technology Acceptance Model. Technology Acceptance Model (TAM) focuses on dealing with the behaviour of teachers and students and prediction. The question of students and teachers in communication generally referred to as technology acceptance model in the literature, interests educational technology researchers, policymakers (investment), and sociologists of education. There are several theories that reflect the issues of technology communication, but not give a full understanding of the influencing communication. This study contributes to the literature about the importance of teacher-student communication/interaction.

\subsubsection{Diffusion of Innovation Theory}

Diffusion of Innovation Theory refers to "how this attitude is formed, how it leads to the eventual adoption or rejection decision and how innovation characteristics fit into this process" (Karahanna, Straub, \& Chervany, 1999). According to Diffusion of Innovation Theory, the attributes of technology that predict teachers and students adoption are ease of use, advantage over existing options, compatibility with prior technologies, values and preferences, easy demonstrability of its results, and trialability of the technology without having to make a huge a prior investment in resources (Venkatesh et al., 2003). Diffusion of Innovation Theory examines a channels' communication, innovation, a social system which influences the spread of a new idea. Diffusion of Innovation theory integrates three chief components: adopter characteristics, characteristics of an innovation, and innovation-decision process. Finally, Diffusion of Innovation Theory mostly focuses on the system characteristics, organizational attributes, and environmental aspects.

\subsubsection{Educational Communications Perspective}

To understand the teaching-learning process as communication better, three models have been developed over the years to explain the evaluation of communication as action, interaction and transaction (Farris et al., 2016). Interactional Communication was used as Interaction Model in this study.

Communication as Interaction Model introduces a feedback from the student to the teacher and students now have the opportunity to deliver messages back to the teacher. Teachers who dominantly serve as the source of messages yet allow students the opportunity to respond to questions and ask questions themselves use this model. This model was chosen by an author as it is compatible with Turkey context. The purpose of this study is to investigate the impacts of 
education technologies on teacher-student communication/interaction by 77 students and 18 teachers in a secondary school in Bursa province.

\subsection{Problem of Research}

Information technologies in education are often related to appropriate computer technologies and the Internet (Vincentas \& Rytis, 2007). Needs-based technology integration education is shown to have a rapid, positive effect on teacher attitudes, such as computer anxiety, perceived importance of computers, and computer enjoyment (Christensen, 2002). Despite all investments on information and communication technology infrastructure, equipments and professional development to improve education in many countries, information and communication technology adoption and integration in teaching and learning have been limited (Andoh, 2012). Studies on the technology used in education are concentrated on computer and Internet database (Koh \& Frick, 2009), preservice teachers' abilities, beliefs (Anderson \& Manninger, 2007; Al-Awidi \& Alghazo, 2012) or understanding the use of technology by classroom teachers (Britten \& Cassady, 2006). However, the technology used in classrooms and the impact of this on communication is not only on the computer. This study is important because it examines and compares the technologies used in the classroom from both teacher and student perspectives. The present study focuses on two limitations in the literature of instructional communication. These include: 1) Difficulty of instructional communication measurement, 2) Limited study with teachers and students together in the measurement of instructional communication.

This study addressed the following research questions:

'What is the impact of educational technology in teacher-student communication?', 'Which technologies do people have to use to support or facilitate each student-teacher communication/interaction?', 'What studies do people have to conduct to determine the efficacy of each technology on students' and teachers' ability to engage in the specific form of communication/interaction?'. In this context, sub-problems are determined: 'What technologies do you use in your classroom?', 'How often do you use it?', 'Do you think lessons learned with these technologies are effective, why?' 'When the technologies in the classroom are taken into account, which technologies affect teacher-student communication?' 'What technologies would you like to use in your classroom to communicate better with your teachers/students in order to handle the lessons better?'

\section{Method}

\subsection{Participants}

The study included a sampling of secondary school students, a typical group for sampling as the impact of educational technologies on student teacher communication will be examined. The sample of the research is composed of students and teachers of a secondary school in Marmara region. 95 people, 77 secondary school students and 18 teachers, participated in the study. The study was carried out with very successful students in one of the best secondary schools in the region. All students were $8^{\text {th }}$ graders, on average 13.8 years old and 35 male/37female. 8 teachers were males, 10 teachers were females who taught mathematics, science at a secondary school in Marmara region of Turkey. Their teaching experience varied, with an average of 22 years of teaching experience and 14.3 years of teaching in this school. Total of 95 teachers/students were reached in their school in February 2019 and the interviews were conducted in their school.

\subsection{Implementation}

Case method is needed to address the gap in the research. This method allows an in-depth and short-time study of one aspect of the researched problem. Case study research refers to an in-depth, a detailed study of an individual or a small group of individuals. Such studies are typically qualitative in nature, resulting in a narrative description of behavior or experience. Case study research is not used to determine cause and effect, nor is it used to discover generalizable truths or make predictions. Rather, the emphasis in case study research is placed on exploration and description of a phenomenon. The main characteristics of case study research are that it is narrowly focused, provides a high level of detail, and is able to combine both objective and subjective data to achieve an in-depth understanding (Creswell, 2013). The data obtained from semi-structured interviews were analyzed by the case study method. In case study, data were analyzed and coded under the purpose of the research. Code that qualifies for similar situations from the codes that are created and themes for the purpose of the research have been created from these codes (Yıldırım \& Şimşek, 2013).

As for the validity of the interview questions prepared by the researchers, two education experts with studies on technology integration and communication, and three language experts with studies on grammar and narrative 
disturbances were consulted. One of the language expert stated that there are expression disorders in a few places in the question and this problem was solved in accordance with his suggestions. In the next phase, an interview was applied to a group of ten people including four teachers working in a secondary school where the researchers are employed, and six students. All participants agreed that the questions were clear, understandable and easy to test.

\subsection{Process}

The research is basically the development of instructional communication impact to improve students learning. Under the model of the study, teachers and students were investigated whether these groups were comparable. Using case study as the methodology provides a means for describing how 18 secondary school teachers and 77 students in one to one interview used the same questions model within their class and the impact of that experience on technology - based learning, student engagement and achievement. Maxqda 11 software program was used in the analysis of the interviews. Coding for participatory expressions on the themes and created themes are presented in the tables. There are also direct quotations from the participants' statements in order to increase the validity of the data and to provide an understanding of the themes and coding presented by the readers. Quotes from participants' references are very important to ensure the validity of the data (Yıldırım \& Şimşek, 2013). Then, the number of codes representing the positive and negative statements stated by the participants is calculated in the Maxqda 11 program. First, the answers given by the participants in the research are listed according to the questions. The minutes of the interview where a problem is not being exploited and is left empty are marked to be removed from the investigation.

At the next stage, the list of themes that have been identified in common areas is grouped by three experts from different disciplines and under the headings to meet these partnerships. A joint study was carried out on the categories by comparing the categories formed by each expert. Finally, each category is classified separately and their themes for the category are placed in the appropriate categories in the Maxqda 11 program. The number and frequencies of the themes are taken from the Maxqda 11 program.

\section{Results}

In this section, the results obtained from the responses of the participants to semi-structured interview questions are presented. The first sub-problem of the students and teachers in the research is "What technologies do you use during your lesson in class and how often do you use them?" And the findings for the students and teachers obtained about this problem situation are presented in the following Figure 2.

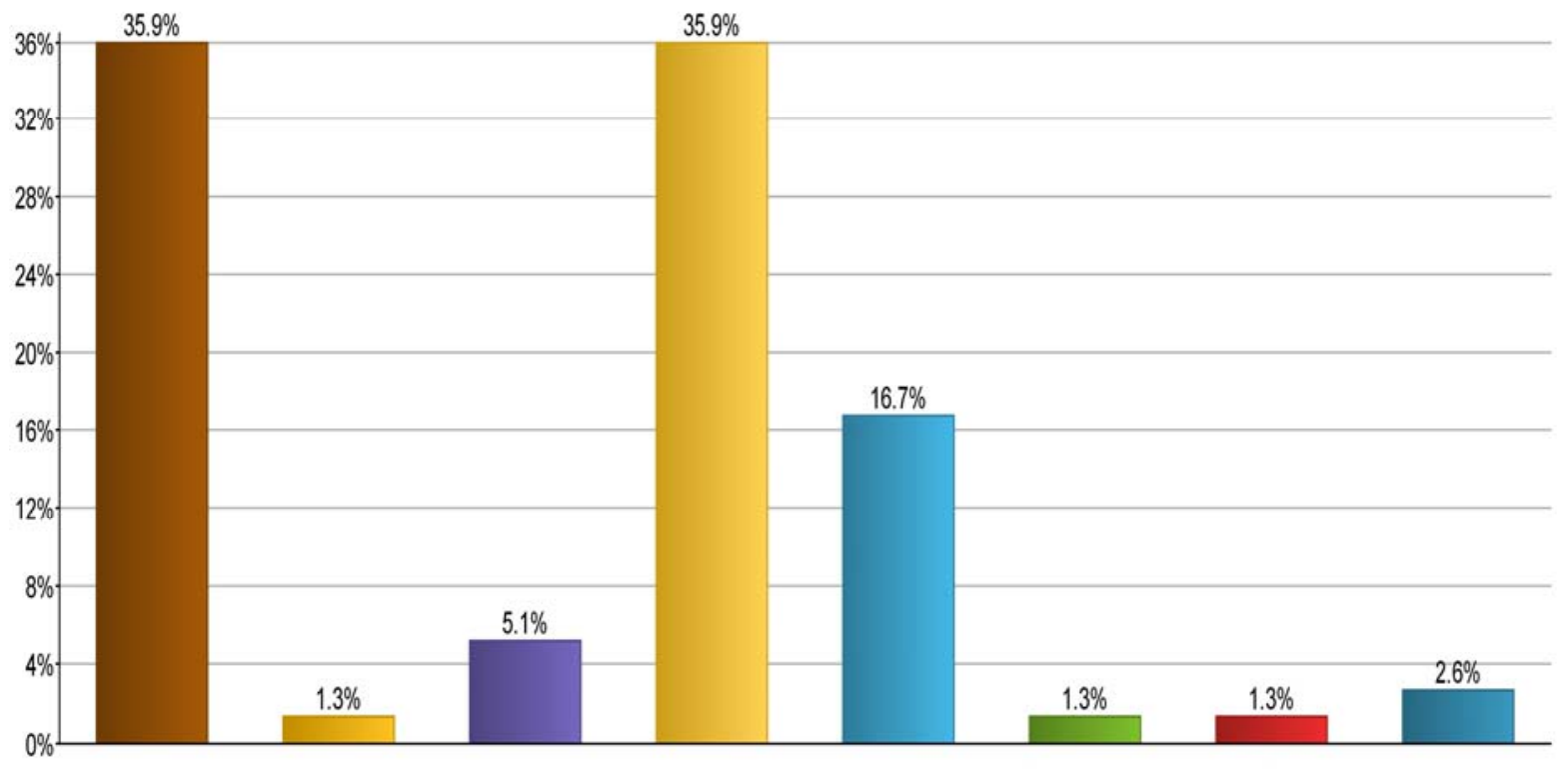

Computers Flash disk Speakers. Smart board. Eraser, desk. Cell phone Board pen Printer

Figure 2. Education Technologies Used in Classrooms According to Students and Frequency of Use 
According to Figure 2, 28 students' computers, 1 student flash disk, 4 student speakers, 27 student smart boards, 13 student erasers and desk, 1 student board pen, 1 student cell phone, 2 student printers are used as technology in the lesson. Table 1 also shows the distribution of the technologies used in the lessons and the opinions of students and teachers about the frequency of use these technologies. Figure 2 shows the differences in usage of education technologies in individuals' frequence distrubution scores as determined by teachers and students. It was observed that there were more prominent differences in computers and smart board compared to others. At first sight, this situation provides also electronic technology, the usage of simple technology such us eraser and desk are high. In addition, eraser and desk are easy to implement, and they have important advantages.

Table 1. The Distribution of Students and Teachers Opininons

\begin{tabular}{lr}
\hline Students opinions & Freqency \\
\hline Sometimes we use computers. & 28 \\
Flash disk. & 1 \\
We use speakers. & 4 \\
Tecnologically we only use smart board. & 27 \\
Eraser, desk. & 13 \\
Sometimes we don't find board-marker. It is good for us. We hate writing. & 1 \\
Sometimes we use cell phone. & 1 \\
Printer & 2 \\
Total & 77 \\
& \\
\hline Teacher opinions & Frequency \\
\hline I use computer everyday. & 1 \\
I use technologies in Science lessons. & 1 \\
Generally use technology. & 1 \\
I use smart board usually. & 1 \\
Only board. & 2 \\
Computer & 5 \\
Pencil & 1 \\
Book & 1 \\
Printer & 4 \\
Cell phone & 1 \\
Total & 18 \\
\hline
\end{tabular}

According to Table 1, one teacher uses computers every day, one teacher uses technological equipment only in science courses, one teacher uses technology generally, one teacher uses smart board generally, two of them uses only smart board, five teachers use computer, one teacher uses pen, one teacher uses book, four teachers use printer, one teacher uses mobile phone.

Figure 3 shows students' opinions on the effectiveness and reason for using technology in lessons. Looking at Figure 3 , from $42^{\text {nd }}$ students to $12^{\text {th }}$ student statement 'No, teacher does not write on the board. When I write, the pen is running out, and this is affecting me negatively." or similar expressions. $30^{\text {th }}$ student said 'Yes, it is very helpful. For example, the simulation is fun." or similar expressions. 


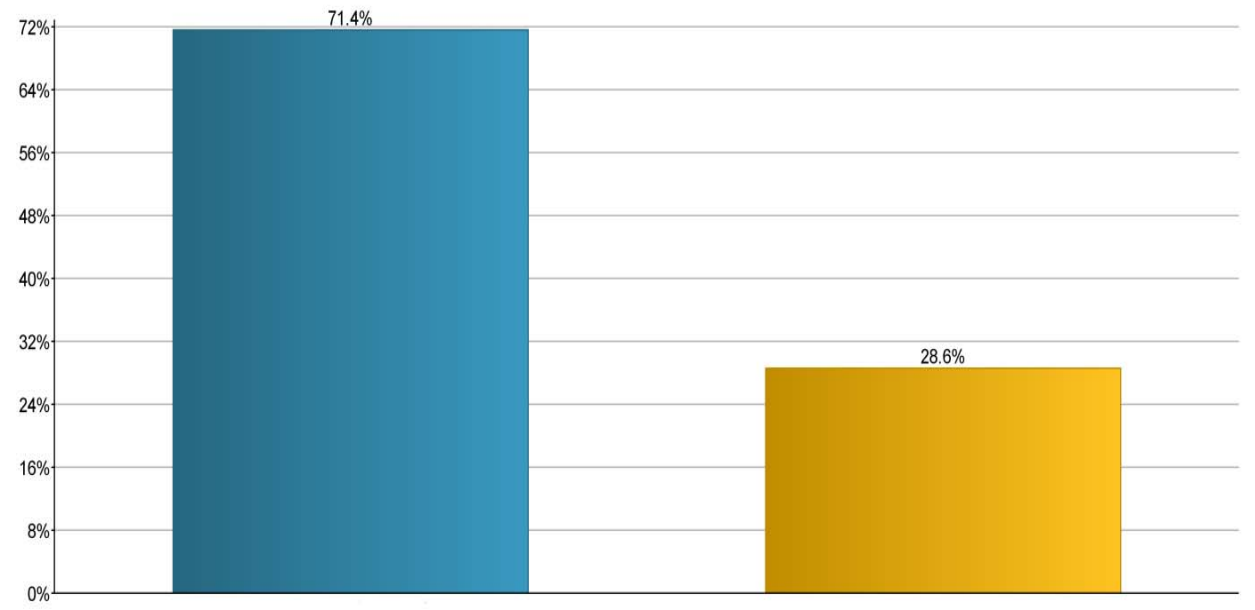

Yes

No

Figure 3. Students' Opinions on Effectiveness and Reason for Using Technology in Lessons

On the other hand, among the statements, it was observed that both effectiveness and reasons were important determinants in students' views about using technology. Figure 4 shows the students' views on the effect of the technologies used on teacher-student communication.

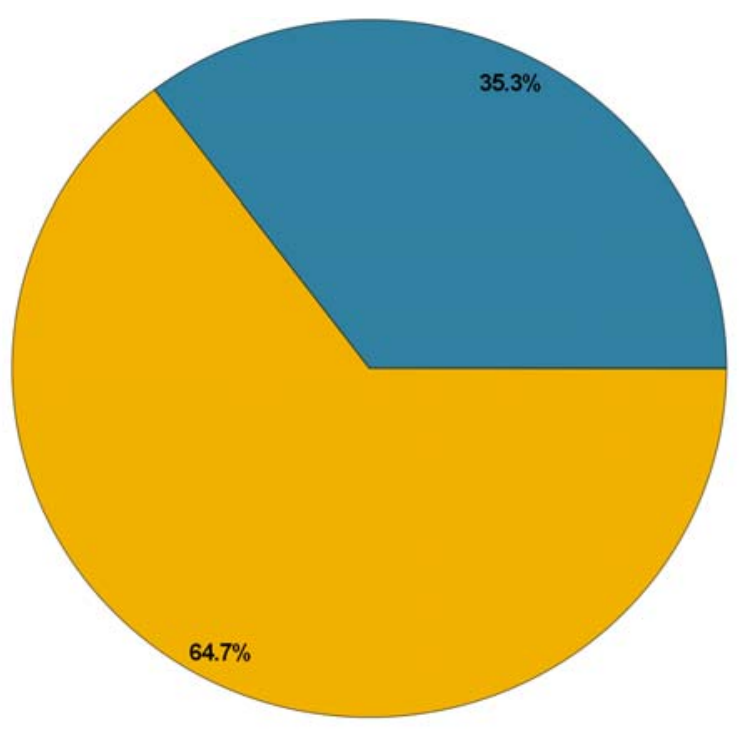

Positive

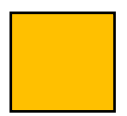

Negative

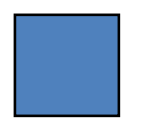

Figure 4. Students' Opinions on the Effect of the Technologies Used on Teacher-Student Communication

Figure 4 shows that 28 students were positive about the effects of the technologies used on communication with the teacher and 49 students indicated that the technological devices used in the classroom negatively affect communication with the teacher. 


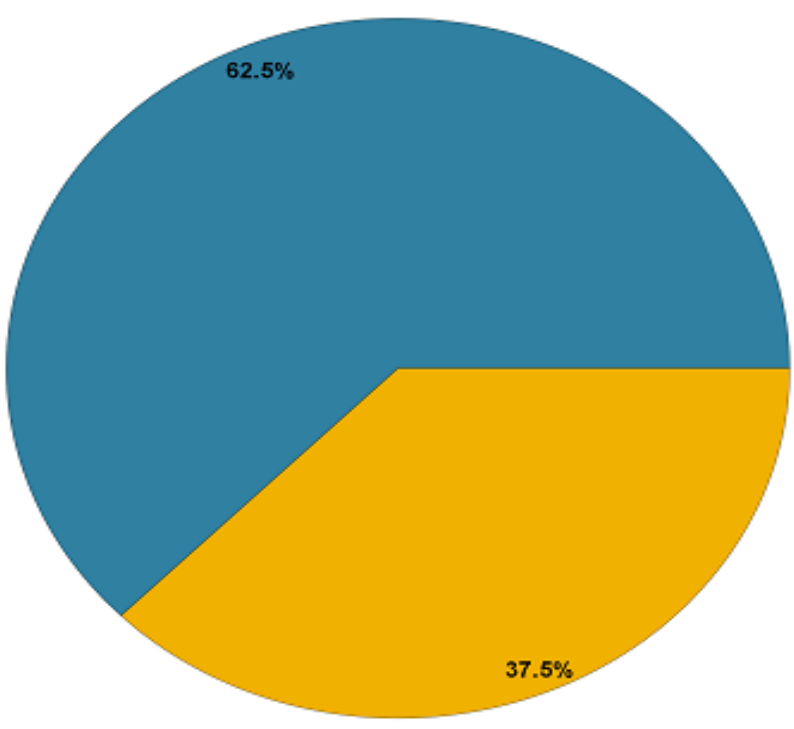

Negative

Positive

Figure 5. Teachers' Opinions on the Impact of the Technologies Used on Teacher-Student Communication

Figure 5, in which teachers' views on the impact of technology used on teacher-student communication/interaction are examined, shows that seven teachers have a negative effect while eleven teachers have a positive influence.

Students' and teachers' wishes are shown in Table 2 in order to understand them better.

Table 2. The Distribution of Students' and Teachers' Wishes to Understand the Lesson Better and Communicate with the Teachers-Students

\begin{tabular}{lc}
\hline Students' answers distribution on wishes & Frequency \\
\hline I'd like painting, music and design in class. & 1 \\
I'd like sound insulation to prevent outside noises. & 8 \\
I'd like a speaker on the walls of every classroom to hear the sound coming out of the computer. & 1 \\
The desk should not be scratched. My writing is corrupted. & 1 \\
I don't have a problem understanding lesson in class. It's not a very distracting situation. & 3 \\
I'd like a technology to detect those who make noise in class. & 1 \\
The teachers' phones must be off in class. & 1 \\
I want air conditioning so we do not open the windows and are not exposed to sounds from & 1 \\
outside. & 2 \\
When there is a smart board, the tablet should not be used, it is distracting. & 1 \\
We'd better express our wishes and thoughts by e-mail. & 1 \\
I think clock is enough. It is enough to see the end of the course. & 2 \\
I would like to have a swatter. & 1 \\
It's not technology, it is class design. I think we should sit in a circle. & 2 \\
I'd like a telescope to examine the objects in the sky. & 2 \\
There could be a poem in the kind of animation named 'Accel world'. & 12 \\
The smart board is very good. & 3 \\
I would like to have a laptop. & 1 \\
It might be better not to use school outfits because we have to constantly fix our clothes. \\
Headset for everyone & 3 \\
Calculator & 1 \\
Math class and music class must be separate & 1 \\
Phone & 1 \\
Shoes without heels for female teachers & 1 \\
\hline
\end{tabular}




\begin{tabular}{|c|c|}
\hline Warning instead of ringing & 1 \\
\hline $\begin{array}{l}\text { First of all, the course should be taught without using technological tools and then can be used } \\
\text { for reuse. }\end{array}$ & 2 \\
\hline For example, the tablet may be dispensed. We agree with the teacher on the tablet. & 22 \\
\hline Heat insulation & 1 \\
\hline Total & 77 \\
\hline Teachers answer distribution & Frequency \\
\hline $\begin{array}{l}\text { The disadvantage of IT technologies is the loss of time. Preparation should be made in advance } \\
\text { to prevent this. }\end{array}$ & 3 \\
\hline $\begin{array}{l}\text { Simplification of the physical environment of the class is not a problem if the distractions are } \\
\text { taken off. }\end{array}$ & 2 \\
\hline $\begin{array}{l}\text { We have not experienced an event that affects our communication in a negative way. Students } \\
\text { learn by having fun with educational technologies. }\end{array}$ & 13 \\
\hline Total & 18 \\
\hline
\end{tabular}

In this section, firstly, it is showed that teachers-students wish to enhance learning, and then sample statements that justify this comparison are given.

\section{Discussion}

The results of this study have implications for practice, specifically related to the effects of using technologies for teacher-student communication. First, technology sourced problems even among teachers and students barriers were determined to exist. Even though there are huge investments in technology used in education, it has been found that this is contradictory in terms of teacher and student communication. In addition, with simple technologies such as sound insulation, the motivation of the students and the teacher-student communication can be increased. It has emerged that students are bored with technology that teachers already have and this creates disruption in communication.

In this study, the alignment among the use of technology in terms of teachers and students was examined. The findings suggest that the use of technology differs in terms of teachers and students influence on teacher student communication/interaction. This shows that the teacher actually believes that communication with the student can be enhanced using technology. However, the opposite is true for students (see Figure 4 \& Figure 5). This study is important to provide evidence that technology practices result in improvement in students' learning. However, it is in contrast to what others reported in the past (Fiksl, Flogie, \& Abersek, 2017). Using technology in the lesson has been perceived by the students as a greater connection/integration, a greater level of satisfaction while working, more teacher support, and more active participation during the classes (Akyürek, 2018). Another important point of the study is that it is designed for the demands of teachers and students regarding technological tools used in class so that the course can be understood better. The majorities of students' complaints about the lack of tablets and sound insulation as teachers are consuming time. In addition to the higher self-efficacy of technology-instruction integration teachers perceived. In summary, these technologies have provided a whole new platform for student learning, and one on which the teachers were quick to capitalize. Teachers might assign barriers about the role technology should play in the classroom (Ertmer et al., 2012). Given the relatively small number of participants in this research, results are not generalizable. In order to verify these results, a larger sample is needed. In this research teachers' and students' practices were not directly observed, but rather inferred from descriptions of practice, provided during interviews.

\section{Conclusion}

The research showed that even when teachers and students have adequate technology to enhance communication/interaction, it is still not a guarantee that they would learn succesfully. As this study demonstrates, it is equally important to provide facilitatory conditions that encourage the integration of technology tools into learning. However, this needs to be ubiquitous technology access to teachers and their students accompanied by a supportive belief and a facilitating organisational construction that supports the use of technology.

\section{Implications}

This research highlights the shortcomings of technology use initiatives on communication/interaction which 
integrated practice of training and teaching. Thus, this research recommends that technology usage proficiency indicators are included in the assessment criteria used to evaluate in teaching practice. This situation will motivate the teachers to make more efforts to use appropriate technology in their lessons.

The results also reveal that there is a need to develop a strong link between students' communication/interaction level and schools to enable teachers to effectively put into practice what they learned. This research also showed even though in essence the politicians have decided to implement technology, there is still more that needs to be done to improve learning and practices. For that reason, decision makers need to craft resource policies that would ensure wider access to technology resources so that teachers and students feel encouraged to adopt it in their lessons.

This research is about communication/interaction effect of technology use by the teachers and students in the school. However, it is equally important to understand the context in which the students were trained for their teaching. In closing, by providing the views of students described in this paper, today's teachers and policy makers can help students develop the communication skills and become the healthy persons of tomorrow.

\section{References}

Akyürek, E. (2018). The Use of Science Cartoons in Science Courses from Science Teachers' Perspectives. International Journal of Eurasia Social Sciences, 9(34), 2303-2312.

Akyürek, E. (2019). Examination of Relationship Science Teachers' Self-Efficacy and Pedagogical Inferences. Kırşehir Eğitim Fakültesi Dergisi, 20(1), 326-339. https://doi.org/10.29299/kefad.2018.20.01.011

Akyürek, E., \& Afacan, Ö. (2018). Problems Encountered During the Scientific Research Process in Graduate Education: The Institute of Educational Sciences. Higher Education Studies, 8(2), 47-57. https://doi.org/10.5539/hes.v8n2p47

Al-Awidi, H. M., \& Alghazo, I. M. (2012). The effect of student teaching experience on preservice elementary teachers' self-efficacy beliefs for technology integration in the UAE. Education Tech Research Dev., 60(5), 923-941. http://doi.org/10.1007/s11423-012-9239-4

Anderson, S. E., \& Maninger, R. M. (2007). Preservice Teachers' Abilities, Beliefs, and Intentions regarding Technology Integration. Journal of Educational Computing Research, 37(2), 151-172. https://doi.org/10.2190/H1M8-562W-18J1-634P

Andoh-Buabeng, C. (2012). Factors influencing teachers' adoption and integration of information and communication technology into teaching: A review of the literature. International Journal of Education and Development using Information and Communication Technology (IJEDICT), 8(1), 136-155.

Asino, T. I., \& Pulay, A. (2019). Student Perceptions on the Role of the Classroom Environment on Computer Supported Collaborative Learning. Tech Trends, https://doi.org/10.1007/s11528-018-0353-y

Britten, J. S., \& Cassady, J. C. (2006). The technology integration assessment instrument. Computers in the Schools, 22, 49-61. https://doi.org/10.1300/J025v22n03_05

Christensen, R. (2002). Effects of technology integration education on the attitudes of teachers and students. Journal of Research on Technology in Education, 34(4), 411-433, https://doi.org/10.1080/15391523.2002.10782359

Creswell, J. W. (2013). Research design: Qualitative, quantitative, and mixed methods approaches. Sage publications.

Crocker, S. G., \& Mazer, J. P. (2019). Associations among community college students' technology apprehension and achievement emotions in developmental education courses. Technology, Pedagogy and Education, 28(1), 37-52, https://doi.org/10.1080/1475939X.2018.1562624

Dhir, A., Gahwaji, N. M., \& Nyman, G. (2013). The role of the iPad in the hands of the learner. Journal of Universal Computer Science, 19(5), 706-727. https://doi.org/10.3217/jucs-019-05-0706

Ertmer, P. A., Ottenbreit-Leftwich, A. T., Sadik, O., Sendurur, E., \& Sendurur, P. (2012). Teacher beliefs and technology integration practices: A critical relationship. Computers \& Education, 59(2), 423-435. https://doi.org/10.1016/j.compedu.2012.02.001.

Farris, K. L., Houser, M. L., \& Hosek, A. M. (2016). Handbook of instructional communication: Rhetorical and instructional perspectives. In M.L. Houser (Ed.), Historical roots and trajectories of instructional 
communication, (pp. 56-74). 2nd Edition. London, England: Routledge.

Fiksl, M., Flogie, A., \& Abersek, B. (2017). Innovative teaching/learning Methods to Improve Science, technology and engineering classroom climate and interest. Journal of Baltic Science Education, 16(6), 1009-1019.

Grigorenko, E., L. (2019). Creativity: a challenge for contemporary education. Comparative Education, 55(1), 116-132, https://doi.org/ 10.1080/03050068.2018.1541665

Jonassen, D. H. (2000). Toward a design theory of problem solving. Educational Technology Research and Development, 48(4), 63-85. https://doi.org/10.1007/BF02300500

Jwaifell, M. (2018). The Proper Use of Technologies as a Digital Citizenship Indicator: Undergraduate English Language Students at Al-Hussein Bin Talal University. World Journal of Education, 8(3), 86-94. https://doi.org/10.5430/wje.v8n3p86

Karahanna, E., Straub, D., \& Chervany, N. (1999). Information Technology Adoption Across Time: A Cross-Sectional Comparison of Pre-Adoption and Post-Adoption Beliefs. MIS Quarterly, 23(2), 183-213. https://doi.org/10.2307/249751

Koh, J. H. L., \& Frick, T. W. (2009). Instructor and Student Classroom Interactions during Technology Skills Instruction for Facilitating Preservice Teachers' Computer Self-Efficacy. Journal of Educational Computing Research, 40(2), 211-228. https://doi.org/10.2190/EC.40.2.d

Lim, C. P., \& Chai, C. S. (2008). Rethinking classroom-oriented instructional development models to mediate instructional planning in technology enhanced learning environments. Teaching and Teacher Education, 24(8), 2002-2013. https://doi.org/10.1016/j.tate.2008.05.004

Marangunić, N., \& Granić, A. (2015). Technology acceptance model: A literature review from 1986 to 2013. Universal Access in the Information Society, 14(1), 81-95. https://doi.org/10.1007/s10209-014-0348-1

Nistor, N., Baltes, B., Dascălu, M., Mihăilă, D., Smeaton, G., \& Trăuşan-Matu, Ş. (2014). Participation in virtual academic communities of practice under the influence of technology acceptance and community factors. A learning analytics application. Computers in Human Behavior, 34(5), 339-344. https://doi.org/10.1016/j.chb.2013.10.051.

Roblyer, M. D., Edwards, J., \& Havriluk, M. A. (2004). Integrating educational technology into teaching (4th ed.). Upper Saddle River, NJ: Prentice Hall.

Siefert, B., Kelly, K., Yearta, L., \& Oliveira, T. (2019). Teacher perceptions and use of technology across content areas with linguistically diverse middle school students. Journal of Digital Learning in Teacher Education, 35(2), 107-121, https://doi.org/ 10.1080/21532974.2019.1568327

Smeets, E. (2005). Does ICT contribute to powerful learning environments in primary education? Computers \& Education, 44(3), 343-355, https://doi.org/10.1016/j.compedu.2004.04.003

Straub, E. T. (2009). Understanding technology adoption: Theory and future directions for informal learning. Review of Educational Research, 79(2), 625-649. https://doi.org/10.3102/0034654308325896

Trucano, M. (2005). Knowledge Maps: ICTs in Education. Washington, DC: infoDev [Pdf]. Retrieved from http://www.infodev.org/files/1062_file_Knowledge Maps_ICTs_and_the_Education_MDGs.pdf

Venkatesh, V., Morris, M., Davis, G., \& Davis, F. (2003). User Acceptance of Information Technology: Toward a Unified View. MIS Quarterly, 27(3), 425-478. https://doi.org/10.2307/30036540

Vincentas, L., \& Rytis, V. (2007). Information communication technologies in natural science education: Situational analysis and prospects in baltic countries. Journal of Baltic Science Education, 6(2), 35-49.

Yıldırım, A., \& Şimşek, H. (2013). Sosyal Bilimlerde Nitel Araştırma Yöntemleri. Seçkin Yayıncılık: Ankara.

Zhang, S., \& Liu, Q. (2019). Investigating the relationships among teachers' motivational beliefs, motivational regulation, and their learning engagement in online professional learning communities. Computers \& Education, 134(7), 145-155. https://doi.org/10.1016/j.compedu.2019.02.013 